JOURNAL OF SECURITY AND SUSTAINABILITY ISSUES

ISSN 2029-7017 print/ISSN 2029-7025 online

2019 December Volume 9 Number 2

http://doi.org/10.9770/jssi.2019.9.2(5)

Scopus

\title{
CLUSTER FUNCTIONING AS A DIRECTION OF SUSTAINABLE TERRITORIAL - INDUSTRIAL PARTNERSHIP
}

\author{
Perizat Beisekova \\ Almaty Technological University, Tolebi Street, 100, Almaty, The Republic of Kazakhstan \\ E-mail: Beisekova_76@mail.ru
}

Received 20 January 2019; accepted 26 September 2019; published 15 December 2019

\begin{abstract}
The development of clusters contributes to the growth of agriculture and processing industry of the republic. The use of the cluster approach corresponds to the nature of agricultural products, which needs processing and timely marketing and delivery to consumers. One of the goals of cluster formation in food production and business development in interrelated industries, along with increasing the competitiveness of national agribusiness products, should be to ensure the safety of final products for consumer health. Agriculture should ensure the safety of the raw materials supplied, food engineering - the safety of equipment on which food products will be manufactured, packaging production - the safety of packaging in contact with foodstuffs.
\end{abstract}

Keywords: cluster; development; industry; equipment; raw materials; structure; agri-food sphere, partnership; innovations

Reference to this paper should be made as follows: Beisekova, P. 2019. Cluster functioning as a direction of sustainable territorial - industrial partnership, Journal of Security and Sustainability Issues 9(2): 421-429. http://doi.org/10.9770/jssi.2019.9.2(5)

JEL Classifications: Q16

\section{Introduction}

One of the promising directions in solving the strategic tasks of sustainable development of Kazakhstan and in the agri-food sector is the creation of integrated structures based on a cluster approach that facilitates import substitution and export orientation of the agricultural sector. This approach assumes the maximum use of the existing productive potential of industries related to food production, modernization and rational distribution of agricultural enterprises, as well as their effective financing (Altukhov, 2019; Moumen et al., 2019). A cluster is a sustainable territorial and sectoral partnership, united by an innovative program to introduce advanced production, engineering and management technologies in order to increase the competitiveness of its participants.

\section{Review of literature and methods of research}

World experience shows that the territorial integration of technologically and economically interconnected structures can improve the logistics of their products and get an additional effect due to the possibility of combining the regional corporate strategy and the competitive advantages of organizations located within its borders. There is a lot of attention to role of clusters and their functioning peculiarities in the contemporary scientific literature (Tireuov et al., 2018; Žižka et al, 2018; Razminienè, Tvaronavičienė, 2018; Havierniková, Kordoš, 2019; Petrenko et al., 2019; Amraoui et al., 2019; Bublienė et al., 2019). We agree, the cluster approach is the basis for the optimal solution of many social, environmental and regional problems in the field of food production (Adamczyk et al., 2019). 
The cluster approach can be successfully applied for the development of agriculture and the processing industry of the Republic. Using the cluster approach corresponds to the nature of agricultural production, which needs quick processing and timely delivery to the consumer. One of the goals of cluster formation in food production and the development of joint business in related industries, along with increasing the competitiveness of agricultural products, should be to ensure the safety of final products for consumer health (Adamczyk et al., 2019; Mahrinasari, 2019). This means that agriculture must ensure the safety of the raw materials supplied, food engineering - the safety of equipment on which food products will be manufactured, and packaging production - the safety of packaging in contact with food (Alimkulova, 2018; Bezpalov et al., 2019).

\section{The discussion of the results}

World experience shows that the territorial integration of technologically and economically interconnected structures allows to improve the logistics of their production and to obtain additional effect due to the possibility of combining the corporate strategy of the region and the competitive advantages of organizations located within its borders. In addition, the cluster approach is the basis for optimal solutions of many social, environmental and regional problems in the field of food production.

The cluster approach can be successfully applied for the development of agriculture and processing industry of the Republic. Using the cluster approach corresponds to the nature of agricultural production, which requires quick processing and timely delivery to the consumer. One of the goals of cluster formation in food production and joint business development of interrelated industries, along with increasing competitiveness of agricultural products, should be to ensure safety of end products for consumer health. This means that agriculture must ensure the security of supply of raw materials, food engineering - equipment safety, which will be manufactured by the food and packing industry safety of packaging in contact with food.

In the last decade, clusters are the most successful tool of economic development of regions in Western countries. The cluster concept represents a new way of doing national economy, and also points to new roles of companies, governments and other organizations. The experience of many countries and regions of the world shows that clusters contribute to the productivity and prosperity where they are used.

The study of domestic and foreign economic theory and management practice proves that in the present time, the clusters are the basic element in the development of the leading national economies. Almost completely the clustering of affected industry Denmark, Finland, Sweden, Norway. Resource, technological, innovative, managerial and competitive advantages of clusters used in the most important sectors of the economy, including food production, biopharmaceutical funds from agricultural raw materials in the countries of South-East Asia, China, Singapore, and Japan. According to experts, to date, clustering covers about $50 \%$ of the economies of leading countries, including USA, Italy, UK, France, Germany and others (Bohdaniuk et al., 2019).

In contemporary world, one of the main directions of increase of efficiency of activity of industrial enterprises formation of agro-industrial clusters is explained by their advantages in comparison with traditional ways of interaction: reducing costs of commodity circulation, the elimination of duplicate functions and the total synergy effect for each participant at the expense of a broader and more comprehensive integration.

Cluster or industrial group is a group of geographically neighbouring interconnected companies and related organizations operating in a certain area and characterized by common activities and complementary to each other. Clusters take various forms depending on their depth and complexity, but in most cases, include the company's finished product or service companies; suppliers of specialized inputs, components, machinery, and services; firms in related industries (Mizanbekova, Bogomolova, 2016).

Clusters often occur naturally. An example is the cluster for processing of agricultural production: farms, processing plants, storage premises operate in a complex and perform their work with certain standards. Cluster 
development is the main direction in improving Kazakhstan's competitiveness on the world market. Guarantee that is its successful application in developed countries like USA, Japan, Germany, Italy. Cluster development in Kazakhstan will bring not only direct economic benefits but also will allow to communicate more effectively the private and public sectors of the economy. The existing system of sectoral approach focuses on horizontal relations, while the cluster approach focuses on the importance of vertical relations between enterprises of different spheres and the interdependent symbiotic relationship, based on synergy. In addition, the cluster perspective changes the role of government and the nature of state intervention.

As a result of interaction of entire groups of industries within clusters contributes to the employment growth, investment, and accelerated the dissemination of advanced technologies in national economy. The countries of the European Union adopted the Scottish model of the cluster in which the core of such a joint production became a major enterprise, which brings together small firms. And there is the Italian model - more flexible and "equitable" cooperation of the enterprises of small, medium and large businesses. The experience of these countries showed that the cluster approach provides a basis for constructive dialogue between representatives of the business sector and the state. It is possible to increase the efficiency of interaction of the private sector, state, trade associations, research and educational institutions in the innovation process.

In the post-socialist countries is more widespread cluster principles of the organization of industrial cooperation at the regional level. This approach provides a great opportunity how to improve the competitiveness of local business and to improve the efficiency of the economic policy of regional authorities.

It should be noted that the boundaries of the clusters may transcend political boundaries. There is an example of European cluster firms in Germany and Switzerland for the production of chemicals.

In conditions of developing economy clusters contain a smaller number of participants, and differ in their social composition. Insufficient number of clusters in developing countries does not mean that these countries were unable to participate to the competition, but it slows down improvement and increased productivity. To improve the incomes, wages and living standards is necessary to increase the productivity and value of products. The region can work more productive, increasing opportunities, improving products and processes, the cluster needs to develop.

Cluster approach allows to achieve accelerated development of small and medium enterprises. Planned the operation and in the long term cluster in the following sectors of Kazakhstan's industry: in machine building, petrochemistry, metallurgy, information technology, biotechnology, grain industry.

The most promising development of the cluster grain processing industry in Akmola, Karaganda, Kostanay, North Kazakhstan regions, the dairy - in Akmola, Almaty, East Kazakhstan, Kostanay and North Kazakhstan regions, in the production and processing of fruit and vegetables in Almaty, Zhambyl, South Kazakhstan regions. The potential of development meat cluster is available in Kostanay, Pavlodar, North Kazakhstan regions, rice - Kyzylorda region, fish - in Atyrau, East Kazakhstan, Karaganda regions.

Despite the existing potential for the creation and development of clusters in several areas at this stage it is advisable to allocate as a pilot three clusters in the grain processing industry (Akmola, Kostanay, NorthKazakhstan region), in the dairy industry (Kostanay region), within the fruit and vegetable industry (Almaty, Zhambyl, South-Kazakhstan region).

This choice was made based on the share of these segments in the food industry, the development of domestic producers in these sectors, the availability of prospects for the production of a product and its export. One of the economic sectors in which there is a favorable environment for creation of clusters is food processing, which are important for sustainable growth of the economy. In January-April 2019 the volume of production in food industry of Kazakhstan amounted to 613 billion tenge, an increase of $2.2 \%$ for the year. This is the maximum production volume in recent years. A significant proportion $(81 \%)$ of the volume traditionally takes the direct production 
of food, in monetary terms, the figure was 496,7 billion were $1.1 \%$ lower than a year earlier.

The growth of production in the food industry have ensured the manufacture of beverages. For 4 months of 2019, the amount of produced drinks made up 116.3 billion tenge - by $19.5 \%$ more than in the same period of 2018 (the index of industrial production - 122\%). Note, support the food industry through the infusion of capital investment declined. Thus, in January-April 2019 total investment in fixed assets in food industry amounted to 25,9 billion tenge, having decreased by $20.9 \%$. The share of investment in the sector amounted to only $0.9 \%$ of total investments in fixed capital of Kazakhstan, a year earlier to $1.2 \%$. Kazakhstan continues to maintain dependence on imported products. in stores $50 \%$ of imported poultry meat, $40 \%$ of imported sausages, $52 \%$ of curds and cheese, and more than $90 \%$ imported from abroad sugar.

Over the past ten years the country imported products at $\$ 10$ billion, and to provide wholly domestic demand in production is possible through integrated measures to support domestic producers. To do this, the national chamber of entrepreneurs of Kazakhstan "Atameken" has developed a detailed plan of import substitution for each industry; the complete elimination of the deficit of sugar (400 thousand tons per year), in Kazakhstan it is necessary to additionally introduce into circulation about 150 thousand hectares of irrigated land and build three new plants for processing of sugar beet. In the first stage, government support can be implemented in the creation of infrastructure for irrigation, and to subsidize the purchase of specialized equipment. It should be noted the three regions, the terms of which allow you to place plants for the manufacture of sugar: Turkestan, Zhambyl and Almaty. To reduce the import of dairy products will be able to build 100 large and 500 medium dairy farms, the annual amount of import substitution will exceed \$ 250 million. In turn, the creation of all three major poultry farms (about 120 billion tenge of investments) to completely eliminate the deficit of poultry meat. Their implementation will allow to ensure food security of Kazakhstan and create thousands of new jobs. The main factors that determine the choice of the method of interaction of the enterprises in the formation of territorial - industrial cluster, the basic principles of improving the relationships of agricultural enterprises are shown in the Figures 1 and Figure 2.

The main factors determining the choice of the method of interaction of the enterprises in the formation of territorial-industrial cluster in AIC

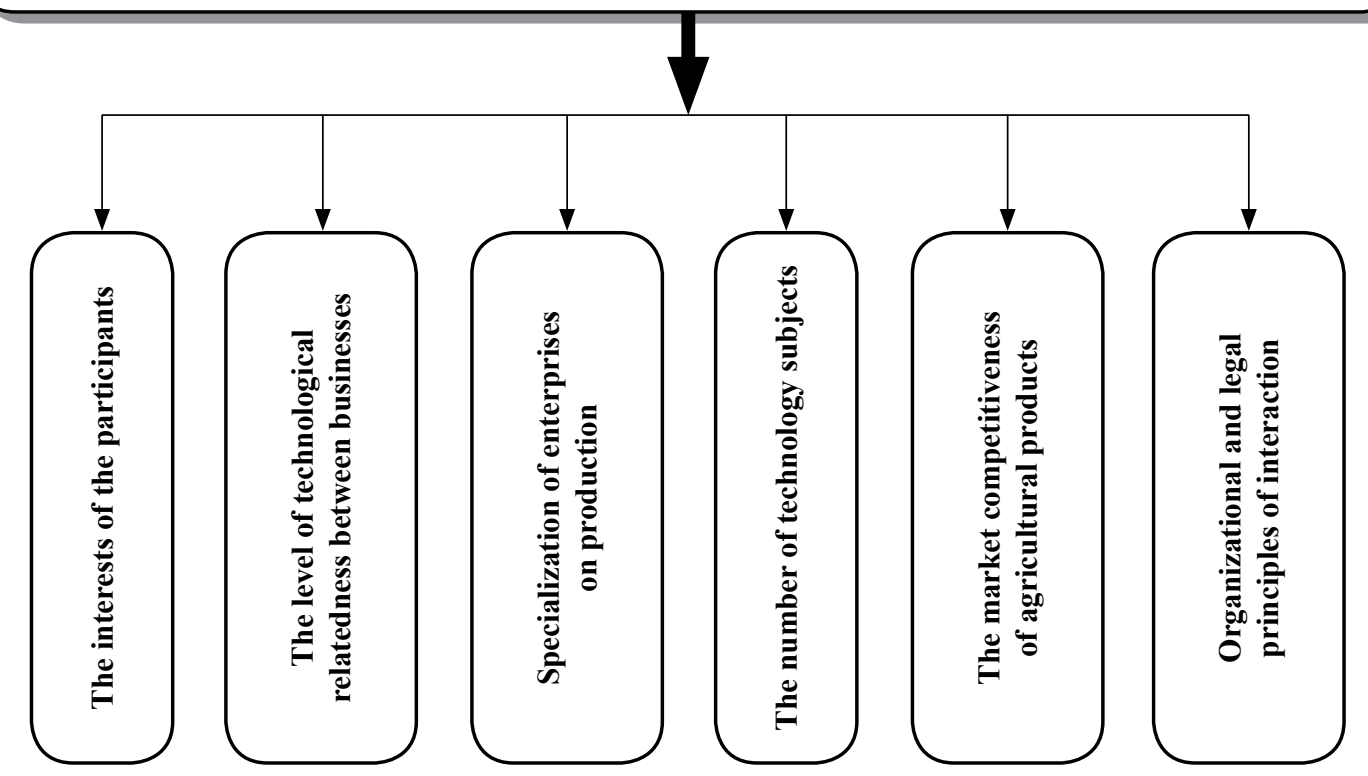

Figure 1. The main factors of interaction of the enterprises in the formation of territorial-industrial cluster in AIC 
To regulate the relationship between members of the cluster ensure their common interests, coordinate the individual and corporate goals, the regulation of domestic product, resource, price and other proportions, it is recommended to use appropriate regulatory mechanisms:

- regulations of exchange-distributive relations;

- the prices of products consumed within the cluster and is implemented end products;

- the profitability ratios of the individual stages of the technological chain;

- the order of formation of the centralized funds in case of their creation;

- financial incentives improve the quality of products (intermediate, final);

- conditions and procedure of mutual settlements.

Priority directions of development of cluster system in the agricultural sector of Kazakhstan are to increase competitive advantage.

- manufacturers of agricultural raw materials by providing favorable economic conditions for their cultivation, stimulating producers to increase agricultural production, ensure their basic means of production (seeds, agricultural equipment, fertilizers, fuel, etc.), the development of large and srednetonazhnykh farms along with the improvement of production and economic activity of households;

- enterprises of the industry processing agricultural raw materials through their modernization, provide hightech, resource-saving equipment, development of waste-free production, deep complex processing of raw materials;

- enterprises system for the procurement, storage, transportation, packing and marketing of agricultural raw materials and finished products through development of alternative forms of procurement and distribution, primary and deep processing of agricultural products and improving wholesale and retail network, the use of effective methods of storing products, etc.;

- development of integrated intersectoral linkages between the agricultural enterprises in the process of moving products from producer to consumer along the technological chain "production-procurement-storageprocessing - transport - packing-realization" on the basis of mutual benefit of mutual inductance sides.

Agriculture of Kazakhstan has a high potential for the development of the grain products cluster. The geographical proximity of the participants (enterprises of food and processing industry, engineering industry, agricultural producers, scientific and educational institutions, enterprises manufacturers of packaging material, etc.), allows you to apply the cluster approach in the development of grain processing industry and the integration of its industries in the global division of labor. The emphasis is on deepening the level and increase the complexity of the system of production, storage, processing and marketing of grain through the modernization of production capacity and increase exports to foreign markets. 


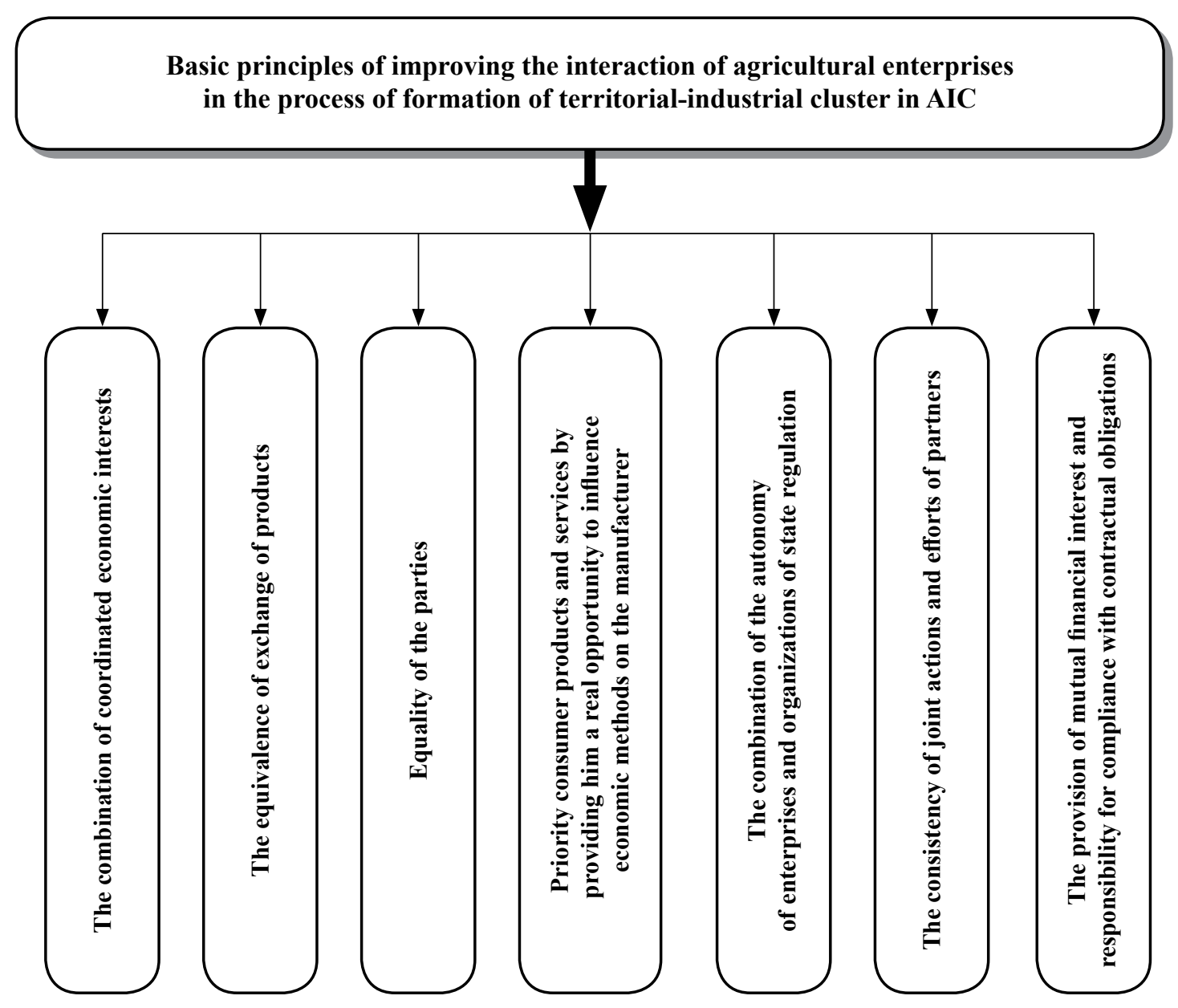

Figure 2. The basic principles in the process of formation of territorial-industrial cluster in AIC

Source: authors

The purpose of formation and development of the grain products cluster is to create conditions for expansion of domestic production and competitiveness of products from the grain on the basis of formation of integration ties between all members of the cluster.

One of the prerequisites for the formation of the grain products cluster is the presence of large vertically integrated structures, technological processes which are carried out with the full system of the closed cycle from raw materials to finished products through its own sales network. Their effective functioning contributed to the development of not only the grain industry but in related industries (livestock, fodder production, poultry, etc.).

Despite some similarities in the orientation of the closed production cycle, principles and mechanisms of creation and activities of industry clusters and agricultural holdings are fundamentally different (Glotko et al., 2013).

To achieve the competitive advantages of individual companies, it is advisable to come together to present a United front to conquer certain segments of the intra-regional and external markets. But the cluster approach is not contrary to the objectives of the integrated formations of holding type, on the contrary their interaction on the basis of cluster principles is one of the most important prerequisites for the competitiveness of grain products and the formation of industry cluster further development of effective forms of interaction of enterprises of the grain industry with its related industries. 
In the process of formation and functioning of the grain products cluster can develop various forms of economic relations between the enterprises - participants. For example economic relations within a single cluster (vertical and horizontal), economic relations between clusters of the main grain regions of Kazakhstan (Akmola, North Kazakhstan and Kostanay regions), and between grain and etc. industry clusters (livestock, etc.). It should be noted that the basis of the grain products cluster in Kazakhstan is of Central Kazakhstan and North Kazakhstan regions. Thus, the share of these regions in the production of grain in the whole, Kazakhstan is approximately $80 \%$ of wheat, $90 \%$ for oats, the buckwheat and the millet $-40-55 \%$ for barley and bean $-70 \%$. In Kazakhstan grain production allows not only to satisfy domestic needs for grain, but also annually to maintain relatively high export potential taking into account the carryover stocks of last years. Kazakhstan today is a major world exporter of grain (included within the top 10 countries by wheat exports). In addition, in recent years, is a leader in flour export (Taubayev, 2012; Petrikov, 2018).

The main competitive advantage of Kazakhstan wheat in the world grain market are high quality indicators (high amount of protein (protein) (over 12.5\%) and gluten (23-28\%), improves quality of flour). Annual share of grain grades 1-3 in Kazakhstan is not less than $70 \%$ of the total harvest. At the same time, demands from the domestic market and importers are forced to intensify efforts to further improve the quality of the wheat. In addition, much work needs to be carried out on the formation of the brand "Kazakh Zerno", as of today Kazakh high-quality wheat remains undervalued on the world market.

So, high-quality soft wheat class 3 from Kazakhstan sold for export as the equivalent of the American or the Russian SRW 4 classes with gluten 18\%, while gluten corresponds to U.S. HRW wheat with protein content of $11.5-12.5 \%$ or spring HRS with a protein content of 14.5-15.5 percent (i.e., hard, with high protein gluten $23-25 \%$ or $28-31 \%$, respectively). The traditional sales markets of grain from Kazakhstan are the countries of Central Asia (Kyrgyzstan, Tajikistan, Turkmenistan, Uzbekistan), the Caucasus (Azerbaijan, Georgia), Iran, Afghanistan and Turkey, with which Kazakhstan has stable relationships in the trade of grain and products of its processing, and can realize stable exports under favorable market conditions One of the promising new directions of export of Kazakh wheat is China and the countries of South-East Asia, the consumer markets which will grow rapidly with the increase of the population (on average, China consumes annually over 100 million tons of wheat.

Depending on the production and consumption of grain regions of Kazakhstan can be figuratively divided into three groups: importing grain; self-sustaining; exporting grain. The first group can be attributed to the following regions: Atyrau, Mangistau, Kyzylorda and South Kazakhstan. The area of arable land per capita 21.3 times lower than in grain-producing areas of the Northern regions and 4.7 times lower than the average for the country.

The second group includes the following areas: Aktobe, Almaty, East Kazakhstan, Zhambyl, West Kazakhstan, Karaganda, Pavlodar region. According to the supply of arable land and other farmland close to the average for the Republic.

The third group includes the major grain producing regions: Akmola, North Kazakhstan and Kostanay region. These regions produce two-thirds of grain in the Republic. Each group has great potential for expansion. Among self-sustaining, you can highlight the ones that have the most favorable economic and climatic conditions for grain production: Pavlodar, Aktobe and West Kazakhstan region. Thus, the structure of the cereal market should be considered, using the concepts of cluster, which allows to identify the interdependence, complementarity between the links, the spread of technology, investment, information, skills and to determine weaknesses that need government support. The cluster consists of the structural units situated in the same area. It allows you to justify the specific mechanism of integration of the structure of the technological cycle "raw materials-processing-sale". 


\section{Conclusions}

The cluster of grain products in Kazakhstan highlighted the following components: grain producing farms, enterprises for grain processing; engineering companies that produce special equipment; packaging enterprises and organizations for standardization and certification of grain enterprises for the production of chemicals and fertilizers, seed companies, HSP, elevators, research institutes and universities, etc. Recognized that can be created with the cluster export-oriented and clusters, focused on the domestic market. Grain products cluster, unlike others, focuses mainly on foreign market, because the grain is of strategic importance to the economy of the Republic and is seen as a driving force of economic growth in the country. Structural transformations based on the cluster approach is fundamentally necessary to improve the competitiveness of enterprises grain and their products.

\section{References:}

Adamczyk, M., Betlej, A., Gondek, J., Ohotina, A. (2019). Technology and sustainable development: towards the future? Entrepreneurship and Sustainability Issues, 6(4), 2003-2016. http://doi.org/10.9770/jesi.2019.6.4(32)

Alimkulova, E.S. (2018). Business cluster development. Agro-market problems, 3, 173 - 179.

Altukhov, A.I. (2019). Agricultural production of the country needs a new concept of placement and specialization. Economics of Agricultural and Processing Enterprises, 8, 7-14.

Amraoui, B., Ouhajjou, A., Monni, S., El Amrani El Idrissi, N., Tvaronavičienė, M. (2019). Performance of clusters in Morocco in the shifting economic and industrial reforms. Insights into Regional Development, 1(3), 227-243. https://doi.org/10.9770/ird.2019.1.3(4)

Bezpalov, V.V., Fedyunin, D.V., Solopova, N.A., Avtonomova, S.A., Lochan, S.A. (2019). A model for managing the innovation-driven development of a regional industrial complex. Entrepreneurship and Sustainability Issues, 6(4), 1884-1896. http://doi.org/10.9770/ jesi.2019.6.4(24)

Bohdaniuk, O., Buriak, R., Savchuk, V. (2019). Competitiveness of horticultural products as a precondition of industry development, Entrepreneurship and Sustainability Issues, 6(4), 1587-1601. https://doi.org/10.9770/jesi.2019.6.4(3)

Bublienè, R., Vinogradova, I., Tvaronavičienè, M., Monni, S. (2019). Legal form determination for the development of clusters ${ }^{\star}$ activities. Insights into Regional Development, 1(3), 244-258. https://doi.org/10.9770/ird.2019.1.3(5)

Glotko, A.V., Kholodov P.P, Ovsyanko, A.L., Grigoriev, N.B. (2013). Model of agro-industrial cluster of the region. AIC: Economy, Management, 6, 80-83.

Havierniková, K., Kordoš, M. (2019). Selected risks perceived by SMEs related to sustainable entrepreneurship in case of engagement into cluster cooperation, Entrepreneurship and Sustainability Issues 6(4): 1680-1693. http://doi.org/10.9770/jesi.2019.6.4(9)

Mahrinasari, M. (2019). Impact of safety concerns on a lifestyle. Journal of Security and Sustainability Issues, 9(1), 269-280. https:// doi.org/10.9770/jssi.2019.9.1(20)

Mizanbekova, S.K., Bogomolova, I.P. (2016). Modern trends of clustering development. Mezdunarodnyj selskochozajstvennyj zurnal, 2, $32-35$.

Moumen, Z., El Idrissi, N.E.A., Tvaronavičienè, M., Lahrach, A. 2019. Water security and sustainable development. Insights into Regional Development, 1(4), 301-317. https://doi.org/10.9770/ird.2019.1.4(2)

Petrenko, Y., Vechkinzova, E., Antonov, V. (2019). Transition from the industrial clusters to the smart specialization of the regions in Kazakhstan. Insights into Regional Development, 1(2), 118-128. https://doi.org/10.9770/ird.2019.1.2(3)

Petrikov, A. (2018). The Use of innovative technologies by different categories of farms and the improvement of scientific and technological policy in agriculture, (AIC): Economics, Management, 9, 4-11.

Razminienè, K., Tvaronavičienè, M. 2018. Detecting the linkages between clusters and circular economy. Terra Economicus, 16(4), 50-65. https://doi.org/10.23683/2073-6606-2018-16-4-50-65

Taubayev, A.A. (2012). Priority directions of innovative modernization of the national economy. Vestnik KEU: Economics, Philosophy, Pedagogy, Jurisprudence. 3(25), 35-38.

Tireuov, K.. Mizanbekova, S., Kalykova, B., Nurmanbekova, G. (2018). Towards food security and sustainable development through en- 
hancing efficiency of grain industry. Enterpreneurship and Sustainability Issues, 6(1), 446-455. http://doi.org/10.9770/jesi.2018.6.1(27)

Žižka, M., Hovorková Valentová, V., Pelloneová, N., Štichhauerová, E. (2018). The effect of clusters on the innovation performance of enterprises: traditional vs new industries. Entrepreneurship and Sustainability Issues, 5(4), 780-794. http://doi.org/10.9770/ jesi.2018.5.4(6)

\section{Perizat BEISEKOVA}

ORCID: 0000-0003-2578-7797

Register for an ORCID ID:

https://orcid.org/register

This work is licensed under the Creative Commons Attribution International License (CC BY).

http://creativecommons.org/licenses/by/4.0/ 